\title{
Human Cancer and Platelet Interaction, a Potential Therapeutic Target
}

\author{
Shike Wang ${ }^{1}$, Zhenyu $\mathrm{Li}^{2}$ and Ren $\mathrm{Xu}^{1,3, *}$ \\ 1 Markey Cancer Center, University of Kentucky, Lexington, KY 40536, USA; Shike.Wang@uky.edu \\ 2 Division of Cardiovascular Medicine, Department of Internal Medicine, College of Medicine, University of \\ Kentucky, 741 South Limestone Street, Lexington, KY 40536, USA; zhenyuli08@uky.edu \\ 3 Department of Molecular and Biomedical Pharmacology, University of Kentucky, Lexington, KY 40536, USA \\ * Correspondence: ren.xu2010@uky.edu; Tel.: +1-859-323-7889; Fax: +1-859-257-6030
}

Received: 2 March 2018; Accepted: 16 April 2018; Published: 20 April 2018

check for updates

\begin{abstract}
Cancer patients experience a four-fold increase in thrombosis risk, indicating that cancer development and progression are associated with platelet activation. Xenograft experiments and transgenic mouse models further demonstrate that platelet activation and platelet-cancer cell interaction are crucial for cancer metastasis. Direct or indirect interaction of platelets induces cancer cell plasticity and enhances survival and extravasation of circulating cancer cells during dissemination. In vivo and in vitro experiments also demonstrate that cancer cells induce platelet aggregation, suggesting that platelet-cancer interaction is bidirectional. Therefore, understanding how platelets crosstalk with cancer cells may identify potential strategies to inhibit cancer metastasis and to reduce cancer-related thrombosis. Here, we discuss the potential function of platelets in regulating cancer progression and summarize the factors and signaling pathways that mediate the cancer cell-platelet interaction.
\end{abstract}

Keywords: cancer metastasis; platelet; biomarker; cancer therapy

\section{Introduction}

During tumor progression, a small number of cancer cells invade into surrounding tissue from the primary lesion and get into the circulation system through the intravastation process [1]. These circulating tumor cells (CTCs) were first identified by Thomas Ashworth in 1869 [2]. Given the recent progress in CTC isolation, the association between CTC and cancer metastasis or prognosis has been identified in many types of cancer, including lung cancer [3,4], breast cancer [5], colon cancer [6] and castration-resistant prostate cancer [7]. In fact, multiple clinical trials have been done or are ongoing to test whether CTC counts can be used as a prognosis marker. The roles of CTCs in cancer metastasis and cancer relapse are well established in animal models [8,9]. Single cell RNA sequencing data show that CTCs exhibit the epithelial-to-mesenchymal transition (EMT) [10] and stem cell phenotypes [11,12], suggesting that CTCs are the driver of cancer metastasis.

CTCs directly interact with red blood cells [13], platelets, macrophages [14], and many other immune cells [15-17]. CTCs also encounter shear stress induced by blood flow [18]. These interactions play important roles in the colonization of CTC at distant organs. It has been shown that CTCs induce the differentiation of macrophages. Cytokines secreted by the differentiated macrophage, in turn, enhances CTC-inflammatory cell interaction, stroma breakdown, and CTC invasion $[19,20]$. Clinical data show that the number of CTC is negatively associated with $\mathrm{CD}^{+} \mathrm{T}$ cells and cytotoxic (CD8 $\left.{ }^{+}\right) \mathrm{T}$ cells [21], suggesting that $\mathrm{T}$ cell-mediated immunity is abnormal in patients with high CTC counts [16]. In addition, programmed death-ligand 1 (PD-L1) expression has been detected on the surface of CTCs, which may contribute to the immune escape from T cells and promote cancer metastasis [22]. 
Clinical evidence and mouse models demonstrate that platelet-cancer cell interaction is crucial for cancer metastasis [23]. Platelets, originally derived from megakaryocytes in the bone marrow [24], are the key regulator of thrombosis $[25,26]$. The major function of platelets is to prevent bleeding and reduce blood loss in case of vascular injury [27]. It has been reported that platelet count is associated with metastasis and poor prognosis in cancer patients $[28,29]$. Consistently, with the clinical evidence, the size and number of tumor nodules are reduced by halving the platelet count in the murine model of ovarian cancer [30]. In addition, long-term application of low-dose anti-platelet drugs, such as aspirin, inhibits cancer metastasis and significantly reduces cancer incidence [31,32]. Together these results suggest that platelet activation is a potential target and prognosis marker for cancer treatment $[29,33,34]$.

In this review, we discuss the function and regulation of cancer cell-platelet interaction during cancer development and progression. We also summarize the factors and pathways mediating the interaction and potential targets to halt platelet-induced cancer progression.

\section{Roles of Platelets in Cancer Development and Progression}

\subsection{Roles of Platelets in Tumor Development}

Platelet activation by physiological agonists results in secretion of a variety of cytokines and growth factors in the platelet releasates (molecules released after platelets activating) [35,36]. Platelet releasates, induced by the agonists of the thrombin receptors, protease activated receptor-1 (PAR1) and PAR4 [37], promote the proliferation of MCF-7 and MDA-MB-231 breast cancer cells and angiogenesis via the phosphoinositide 3-kinase/protein kinase C (PI3K/PKC) pathway [38]. Platelet activation induced by other agonists, including the adenosine diphosphate (ADP) (through its receptor P2Y12 and P2Y1) also promotes tumor growth in ovarian cancer and pancreatic cancer $[39,40]$. Recently, the relationship between P2Y12 and cancer was reviewed by Ballerini et al. indicating the important role of P2Y12 in malignant cells [41].

Many of the platelet-derived factors involved in cancer progression are important components of tumor microenvironment, such as transforming growth factor beta (TGF- $\beta$ ), vascular endothelial growth factor (VEGF), and platelet-derived growth factor (PDGF) [42-44]. TGF- $\beta 1$, a member of the TGF- $\beta$ family, can be secreted during platelets activation [45]. A recent study showed that platelet-derived TGF- $\beta 1$ promotes the growth of primary ovarian cancer in murine models [46]. Incubation of platelets with TGF- $\beta 1$-blocking antibody or downregulation of TGF- $\beta$ R1 receptor expression in cancer cells with siRNA inhibits proliferation in ovarian cancer cells [47]. It has been shown that platelet extracts induce hepatocellular carcinoma growth [48] by suppressing the expression of Krüppel-like factor 6 [49], a tumor suppressor in many cancers [50]. Protein levels of VEGF, PDGF and platelet factor 4 (PF4) in platelets are elevated in colorectal cancer patients compared to healthy control [51]. VEGF and PDGF are the well-characterized angiogenesis regulator [52,53]. It has been shown that platelets induce tumor angiogenesis by releasing platelet-derived growth factor D and VEGF, and subsequently promotes the tumor growth [54]. PF4 accelerates Kras-driven tumorigenesis in lung cancer [55]. Interestingly, PF4 has also been identified as a chemokine that exhibits anti-angiogenesis activity [56] and may inhibit tumor growth through anti-angiogenesis [57]. PF4 may bind to VEGF or basic fibroblast growth factor (bFGF), thereby inhibiting receptor binding and bFGF dimerization $[58,59]$. These results suggest that the function of PF4 in cancer development is context-dependent.

Platelet-derived microRNA has recently been identified as a regulator of tumor development. Lawrence E. Goldfinger showed that platelet-derived microparticles transfer miR-24 into cancer cells. Platelet miR-24 subsequently targets $\mathrm{mt}-\mathrm{Nd} 2$ and Snora75, modulates mitochondrial function, and inhibits tumor growth [60]. Although most data support that platelets promote cancer progression, especially in metastatic dissemination [61,62], this study suggest that the platelets suppress tumor 
development at the initiation stage. Therefore, the function of platelets in cancer progression may be stage- and context-dependent.

\subsection{Roles of Platelets in Cancer Metastasis}

About $90 \%$ cancer related death is due to cancer metastasis [63]. Depletion of platelets or inhibition of platelet activation inhibits cancer metastases [64,65], indicating that platelets are required for cancer metastasis. During metastasis, cancer cells must detach from the primary tumor and intravasate into circulation, where tumor cells encounter immune cells and experience fluid shear stress. The shear force can sensitize both colon and prostate cancer cells to TNF-related apoptosis-inducing ligand (TRAIL)-induced apoptosis [66]. It has been speculated that binding of platelets to cancer cells protects cancer cells from shear-induced damage and facilitates cancer colonization [67].

EMT, characterized by disruption of cell-cell adhesion and expression of mesenchymal markers, provides cancer cells with the increased cell plasticity and stemness required for colonization and metastasis $[68,69]$. Platelet-cancer cell interaction promotes EMT in tumor cells and enhances the rate of tumor extravasation in vivo through the TGF- $\beta /$ Smad and NF- $\kappa$ B pathways $[70,71]$. Platelet microparticles (PMPs) are the most abundant microparticles in the blood, which may transport miRNA and many other factors promoting EMT. For instance, miR-939 in PMPs promotes the EMT by downregulating E-cadherin and claudin by targeting the $3^{\prime} U T R$ region of these genes [72]. In addition, the platelet receptor C-type lectin-like receptor 2(CLEC2) binds to Aggrus expressed in cancer cells and induces the EMT phenotype and cancer metastasis [73]. Tissue factor (TF) is a transmembrane receptor that initiates the extrinsic coagulation pathway. TF is highly expressed in many cancers, and the expression is associated with cancer metastasis [74]. Co-culturing patient-derived ovarian cancer cells with platelets increases the EMT/stemness biomarker and TF protein levels in cancer cells. TF further enhances platelet recruitment and tumorsphere formation [75]. Platelet-released PDGF can also enhance Cyclooxygenase (COX)-2 expression and induce the EMT markers [76]. These studies suggest that platelets promote the EMT process through multiple pathways.

Platelet activation and adhesion depend on integrin signaling [77]. Five integrins, including $\alpha 2 \beta 1$, $\alpha 5 \beta 1, \alpha 6 \beta 1, \alpha \operatorname{Ilb} \beta 3$ and $\alpha v \beta 3$, have been identified in platelets, which bind preferentially to collagen, fibronectin, laminin, vitronectin, and fibrinogen, respectively [78]. It has been shown that platelet $\alpha 6 \beta 1$ mediates the platelet-cancer cell interaction by binding to metalloproteinase (ADAM) 9 on tumor cells, and subsequently induces platelet activation and cancer cell extravasation. Deletion of integrin $\alpha 6 \beta 1$ on platelets reduces lung metastasis [79]. Knockout mouse experiments show that platelet $\beta 3$ integrin contributes to cancer bone metastasis [80]. Treatment with the $\alpha \operatorname{Ilb} \beta 3$ antagonist significantly reduces the bone metastasis of breast cancer in mice though depletion of platelet derived lysophosphatidic acid (LPA) [81]. Interestingly, $\alpha \mathrm{IIb} \beta 3$ expression is also detected on tumor cells [82]; however, roles of the tumor cell $\alpha \mathrm{Ilb} \beta 3$ in cancer metastasis remains unclear.

Anoikis is a programmed cell death induced by cell detachment [83]. Anoikis resistance is required for CTC survival and colonization in distant organs. Platelet interaction protects cancer cells from anoikis [84]. RhoA-(myosin phosphatase targeting subunit 1) MYPT1-protein phosphatase (PP1)-mediated Yes-associated protein 1 (YAP1) dephosphorylation and nuclear translocation are induced by platelets, resulting in apoptosis resistance [85]. Apoptosis signal-regulating kinase 1 (Ask1) is a stress-responsive Ser/Thr mitogen-activated protein kinase kinase kinase (MAP3K) in the Jun N-terminal kinases (JNK) and p38 pathways [86]. Once the Ask1 is deficient in platelet, activating phosphorylation of protein kinase $\mathrm{B}(\mathrm{Akt}), \mathrm{JNK}$, and p38 is reduced, and tumor metastasis is attenuated [87].

Acid sphingomyelinase (Asm) is another secreted protein mediating the interaction between cancer cells and platelets. Asm released from activated platelets induces the production of ceramide. Ceramide activates the $\alpha 5 \beta 1$ integrin on melanoma cells and promotes metastasis in vivo [88]. Treatment with exogenous Asm activates p38 kinase pathway in melanoma cells. Activation of 
p38 is required for tumor cell adhesion and metastasis in vivo [89]. This evidence suggests that platelets promote cancer metastasis through direct and indirect interactions.

\subsection{Impact of Platelet on the Anti-Tumor Immunity}

In order to survive in circulation, CTCs need to overcome not only the shear force-induced damage, but also attacks from immune cells. Antitumor immunity activity is well-characterized in NK cells [90]. Depletion of NK cells significantly promotes cancer metastasis in mouse [91]. It has been shown that binding of platelets protects CTCs from NK cells [92]. MHC class I is usually downregulated in tumor cells [93]. Platelet-derived MHC class I is transferred to tumor cells upon interaction, subsequently reducing the NK cells' antitumor reactivity [94]. In addition, TGF- $\beta$ released by platelets inhibits the anti-tumor activity of NK cells by reducing the expression of natural-killer group 2, member D on NK cells [95].

Platelet-derived TGF- $\beta$ has multiple functions in suppressing the antitumor immunity. TGF- $\beta 1$ is required for converting conventional $\mathrm{CD}^{+} \mathrm{T}$ (Tconv) cells into induced regulatory $\mathrm{T}$ (iTreg) cells [96]. In the hemophilia A mice, TGF- $\beta 1$ along with other platelet contents induces Foxp3 expression in Tconv cells, and then converts them into functional iTreg cells [97]. Treg cells have the ability of killing activated T cells through a granzyme B (GzmB)-dependent mechanism [98,99]. In addition, platelets constitutively express the non-signaling TGF- $\beta$-docking receptor glycoprotein A repetitions predominant (GARP) [100]. Platelet-intrinsic GARP may facilitate TGF- $\beta$ activation in tumor tissue and subsequently constrains the $\mathrm{T}$ cell function in the cancer microenvironment [101]. These data support the hypothesis that platelets promote cancer metastasis by repressing immune response.

\section{Cancer Induces Platelet Activation}

The interaction between platelets and cancer cells is bidirectional, and cancer cells have profound effects on platelet generation and activation. Cancer patients often have an abnormal platelet count and activation. More than five-fold increase of thrombosis and thromboembolism incidences have been detected in cancer patients compared with normal person [102]. Furthermore, the extracellular vesicles derived from breast cancer cell lines induce tissue factor-independent platelet activation and aggregation, providing a potential mechanism for cancer-associated thrombosis [103]. Fiorella Guadagni et al. showed that the cancer-associated oxidative stress also contributes to persistent platelet activation [104].

Cathepsins K (CAT K) is a protease up-regulated in many cancers $[105,106]$. It has been shown that platelet aggregation is induced by CAT K in a dose-dependent manner through proteolytically-activated receptors (PAR) 3 and 4 . During this process, sonic hedgehog, osteoprotegerin, parathyroid hormone-related protein, and TGF- $\beta$ are released, which, in turn, induce downstream signaling pathways in breast cancer cells [107]. This study further suggests that cancer cells have profound impacts on platelet activation.

Levels of lipid phosphate phosphatase 1 (LPP1), the key enzyme in phospholipid biosynthesis pathways, is reduced in platelet derived from ovarian cancer patients. The reduction of LLP1 may contribute to the increased risk of thrombosis in cancer patient [108]. However, plasma levels of $\beta$-thromboglobulin and PF-4, two markers of platelet $\alpha$ granule secretion and platelet aggregation, have little difference between ovarian cancer patient and patients with benign ovarian tumors. In addition, platelets derived from ovarian cancer patients do not exhibit an enhanced aggregation response to ADP or collagen [109]. These findings suggest that platelet hyperactivation in cancer patients is cancer-type dependent.

\section{Platelets, a Potential Therapeutic Target and Biomarker for Cancer Treatment}

\subsection{Platelet Is a Potential Target to Suppresses Cancer Metastasis}

Given the crucial roles of platelets in cancer progression, targeting cancer cell-platelet interaction is considered a promising strategy for cancer prevention and treatment. In fact, many compounds that target platelets exhibit anti-tumor activities. Aspirin is the traditional drug to reduce fever, 
pain, and inflammation [110]. It is also widely used in patients with a high risk of heart disease and thrombosis because of its unique ability to inhibit platelet COX-1 [111]. Treatment with aspirin suppresses the function of platelets in promoting cancer metastasis in mice [112]. Population and clinical studies also demonstrate that aspirin significantly reduces the risk of colon cancer development and inhibits cancer growth and invasiveness $[113,114]$. Tamoxifen is used widely as antiestrogen therapy for breast cancer [115]. Interestingly, one study shows that tamoxifen and its metabolite, 4-hydroxytamoxifen, directly inhibit platelet-mediated metastasis [116]. Specifically, delivery of the platelet aggregation inhibitor ticagrelor to tumor tissue also inhibits the EMT phenotypes and cancer metastasis in vivo [117].

The compound $2 \mathrm{CP}$, a derivative of 4-O-benzoyl-3-methoxy-beta-nitrostyrene, binds to the CLEC-2 and inhibits the platelet aggregation and cancer metastasis in vivo [118]. Phosphodiesterases (PDEs) regulate cyclic nucleotide signaling by catalyzing cyclic adenosine monophosphate (cAMP) and cyclic guanosine monophosphate (cGMP) to the inactive form. PDE2, PDE3, and PDE5 expression is detected in platelets $[119,120]$. Selective PDE inhibitors, such as caffeine and theophylline, inhibit platelet aggregation and cancer cell invasion, and enhance anti-cancer drug efficiency in vivo [121-123]. Glycoprotein IIb/IIIa (GPIIb/IIIa) antagonists inhibit platelet aggregation, and a pre-clinical study shows that treatment with GPIIb/IIIa antagonists significantly decreases tumor nodules in lung metastasis [124].

\subsection{Targeting Platelets Is a Potential Strategy to Overcome Drug Resistance}

The chemotherapeutic response in human epidermal growth factor receptor 2-negative breast cancer is significantly associated with that platelets surround primary tumor [125]. Clinical data show that primary tumor cells surrounded with platelets are less responsive to neo-adjuvant chemotherapy. In addition, platelets promote EMT in cancer cells, which is associated with chemoresistance [126,127]. It has been reported that platelet-derived ADP and ATP increase the level of EMT inducer Slug and cytidine deaminase, and enhances gemcitabine resistance. The P2Y12 inhibitor abolishes the survival signal induced by platelet-derived ADP and ATP [39]. These data suggest that targeting platelets is a potential strategy to overcome chemoresistance.

\subsection{Platelets in Anti-Cancer Drug Delivery}

Platelets, and their secreted vesicles, are potential drug delivery vehicles [128]. Platelets have little effect on drug activity, and using them as drug delivery vehicles may reduce side effects [129]. The platelet-loaded drugs are protected from clearance and, thus, can circulate in blood for a relatively long time [130]. A recent study shows that platelet membrane-coated particles specifically deliver drugs to CTC and reduce cancer lung metastases in mice [131]. Current drug delivery systems depend on unique cancer markers and tumor-specific microenvironment cues, such as $\mathrm{pH}$ and hypoxia. However, the microenvironment of CTCs is different from the solid tumor. Platelets may provide an effective delivery system to target CTCs and inhibit cancer metastasis.

\section{Conclusions and Future Direction}

Platelet-cancer cell interaction promotes cancer cells metastasis by enhancing CTC survival and extravasation (Figure 1). Growth factors, metabolites, and microRNA released by activated platelets induce EMT and enhance cancer cell stemness, which is crucial for cancer cell colonization at the distant organs (Table 1). Importantly, cancer cells also induce platelet activation and aggregation, and subsequently elevate the risk of thrombosis. Therefore, targeting platelet-cancer cell interaction is a potential strategy to reduce both cancer metastasis and cancer-associated thrombosis. Nevertheless, targeting platelets has not been utilized for cancer therapy in the clinic because the cancer cell-platelet interaction is still not completely understood. For instance, the key factor that regulates cancer cell-platelet interaction has not been identified; roles of platelets in tumor initiation and primary 
tumor development remained to be determined. We believe that addressing these questions may help to achieve the goal of targeting platelet-cancer interaction for cancer therapy.

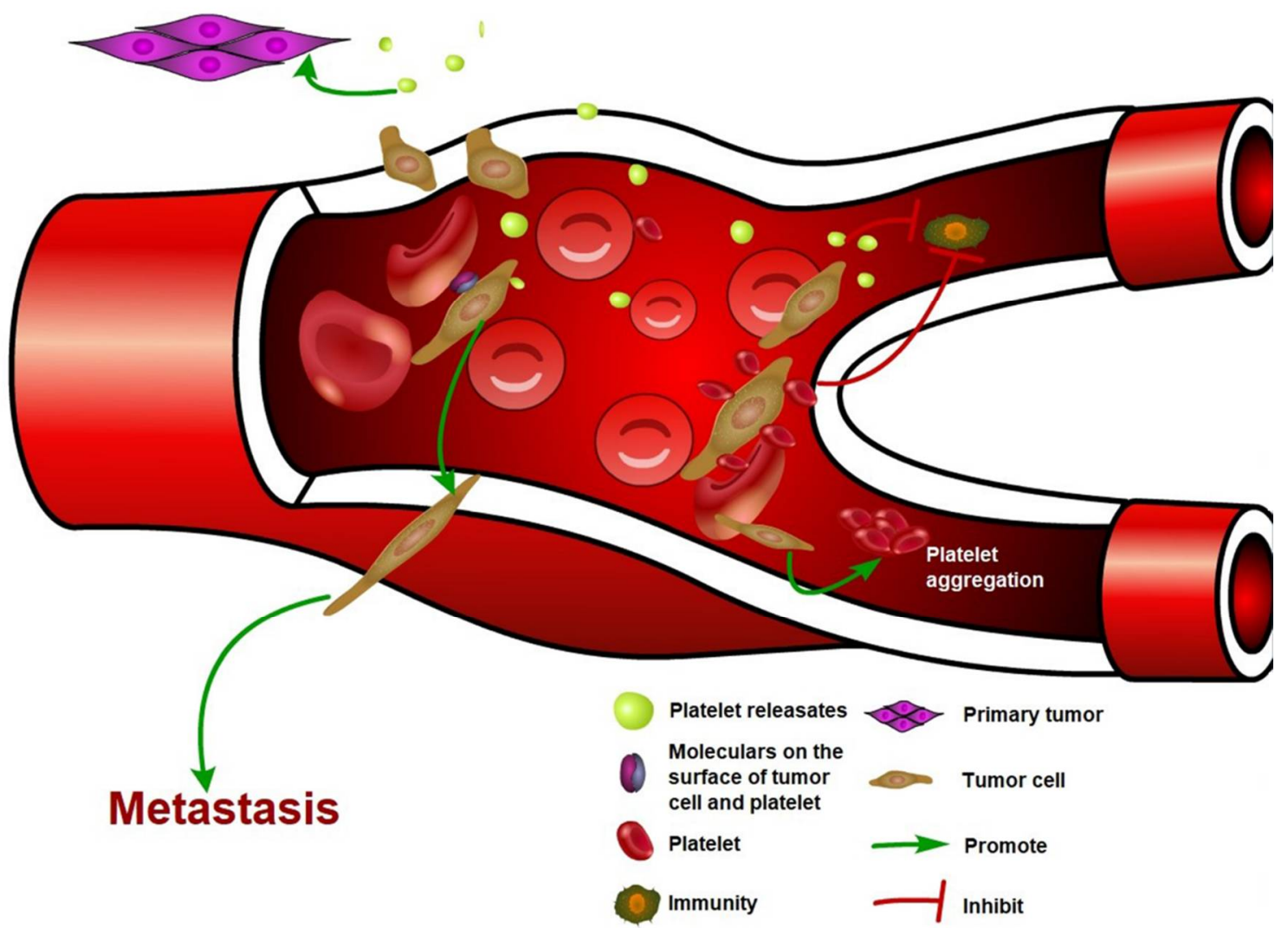

Figure 1. The interaction between cancer cell and platelet. Circulating tumor cells induce platelet activation and aggregation. Activated platelets release a variety of factors, which promote primary tumor growth and cancer metastasis. Binding of platelets also protects CTCs from flow shear force and immune cell attacks. 
Table 1. Function of platelet-derived factors and proteins in cancer development and progression.

\begin{tabular}{|c|c|c|c|c|}
\hline Platelet Related Factors & Function & Mechanism & Inhibitors & Ref. \\
\hline \multirow{5}{*}{ TGF- $\beta$} & Promote primary tumor growth, & TGF- $\beta 1$ promotes cancer cell proliferation directly & \multirow{5}{*}{ SB431542, decorin } & {$[46,47]$} \\
\hline & \multirow{2}{*}{$\begin{array}{l}\text { Enhance EMT phenotype and promote tumor } \\
\text { cell extravasation }\end{array}$} & $\begin{array}{l}\text { TGF- } \beta \text { releasing induces the EMT phenotype depending } \\
\text { on podoplanin }\end{array}$ & & {$[70,71]$} \\
\hline & & $\begin{array}{l}\text { Platelets and tumor cells contacts activate TGF- } \beta \text { /SMAD } \\
\text { and NF- } k \text { b pathway }\end{array}$ & & \\
\hline & \multirow{2}{*}{$\begin{array}{l}\text { Downregulate reactivity of NK cell, } \\
\text { inhibit antitumor immunity }\end{array}$} & $\begin{array}{l}\text { TGF- } \beta \text { down-regulates the NKG2D expression, the } \\
\text { activating immunoreceptor }\end{array}$ & & {$[95,96]$} \\
\hline & & TGF- $\beta$ downregulates inflammatory cytokine production & & \\
\hline VEGF & Promote the angiogenesis & Enhance endothelial cell growth & & [52] \\
\hline \multirow[t]{2}{*}{ PDGF } & Promote the tumorigenesis & $\begin{array}{c}\text { Stimulate the cells in tumor stroma and promote } \\
\text { angiogenesis }\end{array}$ & \multirow{2}{*}{$\begin{array}{l}\text { Olaratumab, imatinib, sunitinib, sorafenib, } \\
\text { pazopa-nib, nilotinib, cediranib, trapidil }\end{array}$} & [53] \\
\hline & Induce EMT markers & Upregulate the expression of COX-2 & & [76] \\
\hline \multirow{2}{*}{ PF4 } & Inhibit tumor growth and metastasis & $\begin{array}{l}\text { Inhibit endothelial proliferation in vitro and } \\
\text { angiogenesis in vivo }\end{array}$ & & [57] \\
\hline & Promote Kras-driven tumorigenensis & $\begin{array}{l}\text { Promote platelet production and modulate the tumor } \\
\text { mocroenvironment to accelerate the tumor growth }\end{array}$ & & [55] \\
\hline \multirow{2}{*}{$\mathrm{P} 2 \mathrm{Y} 12$} & \multirow{2}{*}{ Promote primary tumor growth } & $\begin{array}{l}\text { Recruits } G \beta \gamma \text { subunits, causing phosphoinositide-3-kinase- } \\
\text { dependent Akt phosphorylation and Rap1b activation }\end{array}$ & \multirow[t]{2}{*}{ clopidogrel, ticagrelor, prasugrel } & \multirow[t]{2}{*}[40,41]{} \\
\hline & & Induce ERK1/2 and paxillin Ser83 phosphorylation & & \\
\hline MiRNA 24 & Induce the tumor growth inhibition at early stage & $\begin{array}{l}\text { Transfer to tumor cells, then induce the mitochondrial } \\
\text { dysfunction and tumor cell apoptosis }\end{array}$ & & [60] \\
\hline MiRNA 939 & promotes epithelial to mesenchymal transition & $\begin{array}{l}\text { Transfer to tumor cells, downregulate E-cadherin and } \\
\text { up-regulate vimentin }\end{array}$ & & [72] \\
\hline CLEC2 & Promote EMT and tumor extravasation in mouse model & $\begin{array}{l}\text { Bind with Aggrus, attenuate Aggrus-induced } \\
\text { platelet aggregation }\end{array}$ & 2A2B10, 2CP & [73] \\
\hline Integrin $(\alpha 6 \beta 1, \alpha \operatorname{Ilb} \beta 3)$ & Promote metastasis & Bind with molecular on tumor cell surface, such as ADAM9 & ML464, scFv Ab; A11, 7E3 F(ab')2 & {$[79,80]$} \\
\hline LPA & Enhance bone metastasis & $\begin{array}{l}\text { enhances the LPA-dependent production of IL- } 6 \text { and IL- } 8 \text { to } \\
\text { stimulate osteoclast-mediated bone resorption }\end{array}$ & & [81] \\
\hline Asm & Promote tumor cell adhesion and metastasis & Activate $\alpha 5 \beta 1$ on melanoma cells & & [88] \\
\hline Ask1 & Promote cancer metastasis & Protect the cancer cells from anoikis & & {$[86,87]$} \\
\hline
\end{tabular}


Acknowledgments: This study was supported by start-up funding from Markey Cancer Center and funding support from NCI (1R01CA207772, 1R01CA215095, and 1R21CA209045 to Ren Xu) and the United States Department of Defense (W81XWH-15-1-0052 to Ren Xu).

Author Contributions: Shike Wang and Ren $\mathrm{Xu}$ wrote the manuscript, and Zhenyu Li read and revised the manuscript.

Conflicts of Interest: The authors declare no conflict of interest.

\section{Abbreviations}

$\begin{array}{ll}\text { VEGF } & \text { Vascular endothelial growth factor } \\ \text { PDGF } & \text { Platelet derived growth factor } \\ \text { P2Y12 } & \text { Platelet factor 4 (PF4), ADP receptor } \\ \text { CLEC2 } & \text { C-type lectin-like receptor 2 } \\ \text { LPA } & \text { Lysophosphatidic acid } \\ \text { Asm } & \text { Acid sphingomyelinase } \\ \text { Ask1 } & \text { Apoptosis signal-regulating kinase 1 }\end{array}$

\section{References}

1. Gupta, G.P.; Massague, J. Cancer metastasis: Building a framework. Cell 2006, 127, 679-695. [CrossRef] [PubMed]

2. Ashworth, T.R. A case of cancer in which cells similar to those in the tumors were seen in the blood after death. Aust. Med. J. 1869, 14, 146-149.

3. Aggarwal, C.; Wang, X.; Ranganathan, A.; Torigian, D.; Troxel, A.; Evans, T.; Cohen, R.B.; Vaidya, B.; Rao, C.; Connelly, M.; et al. Circulating tumor cells as a predictive biomarker in patients with small cell lung cancer undergoing chemotherapy. Lung Cancer 2017, 112, 118-125. [CrossRef] [PubMed]

4. Tartarone, A.; Lerose, R.; Rodriquenz, M.G.; Mambella, G.; Calderoni, G.; Bozza, G.; Aieta, M. Molecular characterization and prognostic significance of circulating tumor cells in patients with non-small cell lung cancer. J. Thorac. Dis. 2017, 9 (Suppl. 13), S1359-S1363. [CrossRef] [PubMed]

5. Cristofanilli, M.; Budd, G.T.; Ellis, M.J.; Stopeck, A.; Matera, J.; Miller, M.C.; Reuben, J.M.; Doyle, G.V.; Allard, W.J.; Terstappen, L.W.; et al. Circulating tumor cells, disease progression, and survival in metastatic breast cancer. N. Engl. J. Med. 2004, 351, 781-791. [CrossRef] [PubMed]

6. Cohen, S.J.; Punt, C.J.; Iannotti, N.; Saidman, B.H.; Sabbath, K.D.; Gabrail, N.Y.; Picus, J.; Morse, M.A.; Mitchell, E.; Miller, M.C.; et al. Prognostic significance of circulating tumor cells in patients with metastatic colorectal cancer. Ann. Oncol. 2009, 20, 1223-1229. [CrossRef] [PubMed]

7. De Bono, J.S.; Scher, H.I.; Montgomery, R.B.; Parker, C.; Miller, M.C.; Tissing, H.; Doyle, G.V.; Terstappen, L.W.; Pienta, K.J.; Raghavan, D. Circulating tumor cells predict survival benefit from treatment in metastatic castration-resistant prostate cancer. Clin. Cancer Res. 2008, 14, 6302-6309. [CrossRef] [PubMed]

8. Zhang, S.; Wu, T.; Peng, X.; Liu, J.; Liu, F.; Wu, S.; Liu, S.; Dong, Y.; Xie, S.; Ma, S. Mesenchymal phenotype of circulating tumor cells is associated with distant metastasis in breast cancer patients. Cancer Manag. Res. 2017, 9, 691-700. [CrossRef] [PubMed]

9. Thiele, J.A.; Bethel, K.; Kralickova, M.; Kuhn, P. Circulating Tumor Cells: Fluid Surrogates of Solid Tumors. Annu. Rev. Pathol. 2017, 12, 419-447. [CrossRef] [PubMed]

10. Ting, D.T.; Wittner, B.S.; Ligorio, M.; Vincent Jordan, N.; Shah, A.M.; Miyamoto, D.T.; Aceto, N.; Bersani, F.; Brannigan, B.W.; Xega, K.; et al. Single-cell RNA sequencing identifies extracellular matrix gene expression by pancreatic circulating tumor cells. Cell Rep. 2014, 8, 1905-1918. [CrossRef] [PubMed]

11. Okumura, T.; Yamaguchi, T.; Watanabe, T.; Nagata, T.; Shimada, Y. Flow Cytometric Detection of Circulating Tumor Cells Using a Candidate Stem Cell Marker, p75 Neurotrophin Receptor (p75NTR). Methods Mol. Biol. 2017, 1634, 211-217. [PubMed]

12. Mirza, S.; Jain, N.; Rawal, R. Evidence for circulating cancer stem-like cells and epithelial-mesenchymal transition phenotype in the pleurospheres derived from lung adenocarcinoma using liquid biopsy. Tumour Biol. 2017, 39. [CrossRef] [PubMed]

13. Takeishi, N.; Imai, Y.; Yamaguchi, T.; Ishikawa, T. Flow of a circulating tumor cell and red blood cells in microvessels. Phys. Rev. E 2015, 92. [CrossRef] [PubMed]

14. Hamilton, G.; Rath, B. Circulating tumor cell interactions with macrophages: Implications for biology and treatment. Transl. Lung Cancer Res. 2017, 6, 418-430. [CrossRef] [PubMed] 
15. Gruber, I.; Landenberger, N.; Staebler, A.; Hahn, M.; Wallwiener, D.; Fehm, T. Relationship between circulating tumor cells and peripheral T-cells in patients with primary breast cancer. Anticancer Res. 2013, 33, 2233-2238. [PubMed]

16. Mego, M.; Gao, H.; Cohen, E.N.; Anfossi, S.; Giordano, A.; Sanda, T.; Fouad, T.M.; De Giorgi, U.; Giuliano, M.; Woodward, W.A.; et al. Circulating Tumor Cells (CTC) Are Associated with Defects in Adaptive Immunity in Patients with Inflammatory Breast Cancer. J. Cancer 2016, 7, 1095-1104. [CrossRef] [PubMed]

17. Lin, M.; Liang, S.Z.; Shi, J.; Niu, L.Z.; Chen, J.B.; Zhang, M.J.; Xu, K.C. Circulating tumor cell as a biomarker for evaluating allogenic NK cell immunotherapy on stage IV non-small cell lung cancer. Immunol. Lett. 2017, 191, 10-15. [CrossRef] [PubMed]

18. McCarty, O.J.; Ku, D.; Sugimoto, M.; King, M.R.; Cosemans, J.M.; Neeves, K.B. Dimensional analysis and scaling relevant to flow models of thrombus formation: Communication from the SSC of the ISTH. J. Thromb. Haemost. 2016, 14, 619-622. [CrossRef] [PubMed]

19. Unsicker, K.; Spittau, B.; Krieglstein, K. The multiple facets of the TGF-beta family cytokine growth/differentiation factor-15/macrophage inhibitory cytokine-1. Cytokine Growth Factor Rev. 2013, 24, 373-384. [CrossRef] [PubMed]

20. Hamilton, G.; Rath, B.; Klameth, L.; Hochmair, M.J. Small cell lung cancer: Recruitment of macrophages by circulating tumor cells. Oncoimmunology 2016, 5, e1093277. [CrossRef] [PubMed]

21. Sun, W.W.; Xu, Z.H.; Lian, P.; Gao, B.L.; Hu, J.A. Characteristics of circulating tumor cells in organ metastases, prognosis, and T lymphocyte mediated immune response. Onco Targets Ther. 2017, 10, 2413-2424. [CrossRef] [PubMed]

22. Wang, X.; Sun, Q.; Liu, Q.; Wang, C.; Yao, R.; Wang, Y. CTC immune escape mediated by PD-L1. Med. Hypotheses 2016, 93, 138-139. [CrossRef] [PubMed]

23. Stone, J.P.; Wagner, D.D. P-selectin mediates adhesion of platelets to neuroblastoma and small cell lung cancer. J. Clin. Investig. 1993, 92, 804-813. [CrossRef] [PubMed]

24. Machlus, K.R.; Thon, J.N.; Italiano, J.E., Jr. Interpreting the developmental dance of the megakaryocyte: A review of the cellular and molecular processes mediating platelet formation. Br. J. Haematol. 2014, 165, 227-236. [CrossRef] [PubMed]

25. Didelot, M.; Docq, C.; Wahl, D.; Lacolley, P.; Regnault, V.; Lagrange, J. Platelet aggregation impacts thrombin generation assessed by calibrated automated thrombography. Platelets 2017, 1-6. [CrossRef] [PubMed]

26. Davi, G.; Patrono, C. Platelet activation and atherothrombosis. N. Engl. J. Med. 2007, 357, 2482-2494. [CrossRef] [PubMed]

27. Versteeg, H.H.; Heemskerk, J.W.; Levi, M.; Reitsma, P.H. New fundamentals in hemostasis. Physiol. Rev. 2013, 93, 327-358. [CrossRef] [PubMed]

28. Zhang, M.; Huang, X.Z.; Song, Y.X.; Gao, P.; Sun, J.X.; Wang, Z.N. High Platelet-to-Lymphocyte Ratio Predicts Poor Prognosis and Clinicopathological Characteristics in Patients with Breast Cancer: A Meta-Analysis. BioMed Res. Int. 2017, 2017. [CrossRef] [PubMed]

29. Tjon-Kon-Fat, L.A.; Lundholm, M.; Schroder, M.; Wurdinger, T.; Thellenberg-Karlsson, C.; Widmark, A.; Wikstrom, P.; Nilsson, R.J.A. Platelets harbor prostate cancer biomarkers and the ability to predict therapeutic response to abiraterone in castration resistant patients. Prostate 2018, 78, 48-53. [CrossRef] [PubMed]

30. Stone, R.L.; Nick, A.M.; McNeish, I.A.; Balkwill, F.; Han, H.D.; Bottsford-Miller, J.; Rupairmoole, R.; Armaiz-Pena, G.N.; Pecot, C.V.; Coward, J.; et al. Paraneoplastic thrombocytosis in ovarian cancer. N. Engl. J. Med. 2012, 366, 610-618. [CrossRef] [PubMed]

31. Rothwell, P.M.; Wilson, M.; Price, J.F.; Belch, J.F.; Meade, T.W.; Mehta, Z. Effect of daily aspirin on risk of cancer metastasis: A study of incident cancers during randomised controlled trials. Lancet 2012, 379, 1591-1601. [CrossRef]

32. Patrignani, P.; Patrono, C. Aspirin and Cancer. J. Am. Coll. Cardiol. 2016, 68, 967-976. [CrossRef] [PubMed]

33. Fu, S.; Niu, Y.; Zhang, X.; Zhang, J.R.; Liu, Z.P.; Wang, R.T. Squamous cell carcinoma antigen, platelet distribution width, and prealbumin collectively as a marker of squamous cell cervical carcinoma. Cancer Biomark. 2017, 21, 317-321. [CrossRef] [PubMed]

34. Liu, W.; Ha, M.; Yin, N. Combination of platelet count and lymphocyte to monocyte ratio is a prognostic factor in patients undergoing surgery for non-small cell lung cancer. Oncotarget 2017, 8, 73198-73207. [CrossRef] [PubMed] 
35. Sheu, J.R.; Fong, T.H.; Liu, C.M.; Shen, M.Y.; Chen, T.L.; Chang, Y.; Lu, M.S.; Hsiao, G. Expression of matrix metalloproteinase-9 in human platelets: Regulation of platelet activation in in vitro and in vivo studies. Br. J. Pharmacol. 2004, 143, 193-201. [CrossRef] [PubMed]

36. Pintucci, G.; Froum, S.; Pinnell, J.; Mignatti, P.; Rafii, S.; Green, D. Trophic effects of platelets on cultured endothelial cells are mediated by platelet-associated fibroblast growth factor-2 (FGF-2) and vascular endothelial growth factor (VEGF). Thromb. Haemost. 2002, 88, 834-842. [CrossRef] [PubMed]

37. Ma, L.; Perini, R.; McKnight, W.; Dicay, M.; Klein, A.; Hollenberg, M.D.; Wallace, J.L. Proteinase-activated receptors 1 and 4 counter-regulate endostatin and VEGF release from human platelets. Proc. Natl. Acad. Sci. USA 2005, 102, 216-220. [CrossRef] [PubMed]

38. Jiang, L.; Luan, Y.; Miao, X.; Sun, C.; Li, K.; Huang, Z.; Xu, D.; Zhang, M.; Kong, F.; Li, N. Platelet releasate promotes breast cancer growth and angiogenesis via VEGF-integrin cooperative signalling. Br. J. Cancer 2017, 117, 695-703. [CrossRef] [PubMed]

39. Elaskalani, O.; Falasca, M.; Moran, N.; Berndt, M.C.; Metharom, P. The Role of Platelet-Derived ADP and ATP in Promoting Pancreatic Cancer Cell Survival and Gemcitabine Resistance. Cancers 2017, 9, 142. [CrossRef] [PubMed]

40. Cho, M.S.; Noh, K.; Haemmerle, M.; Li, D.; Park, H.; Hu, Q.; Hisamatsu, T.; Mitamura, T.; Mak, S.L.C.; Kunapuli, S.; et al. Role of ADP receptors on platelets in the growth of ovarian cancer. Blood 2017, 130, 1235-1242. [CrossRef] [PubMed]

41. Ballerini, P.; Dovizio, M.; Bruno, A.; Tacconelli, S.; Patrignani, P. P2Y12 Receptors in Tumorigenesis and Metastasis. Front. Pharmacol. 2018, 9, 66. [CrossRef] [PubMed]

42. Waldmann, T.A. Cytokines in Cancer Immunotherapy. Cold Spring Harb. Perspect. Biol. 2017. [CrossRef] [PubMed]

43. Musolino, C.; Allegra, A.; Innao, V.; Allegra, A.G.; Pioggia, G.; Gangemi, S. Inflammatory and Anti-Inflammatory Equilibrium, Proliferative and Antiproliferative Balance: The Role of Cytokines in Multiple Myeloma. Mediat. Inflamm. 2017, 2017. [CrossRef] [PubMed]

44. Lee, M.; Rhee, I. Cytokine Signaling in Tumor Progression. Immune Netw. 2017, 17, 214-227. [CrossRef] [PubMed]

45. Assoian, R.K.; Komoriya, A.; Meyers, C.A.; Miller, D.M.; Sporn, M.B. Transforming growth factor-beta in human platelets. Identification of a major storage site, purification, and characterization. J. Biol. Chem. 1983, 258, 7155-7160. [PubMed]

46. Hu, Q.; Hisamatsu, T.; Haemmerle, M.; Cho, M.S.; Pradeep, S.; Rupaimoole, R.; Rodriguez-Aguayo, C.; Lopez-Berestein, G.; Wong, S.T.C.; Sood, A.K.; et al. Role of Platelet-Derived Tgfbeta1 in the Progression of Ovarian Cancer. Clin. Cancer Res. 2017, 23, 5611-5621. [CrossRef] [PubMed]

47. Cho, M.S.; Bottsford-Miller, J.; Vasquez, H.G.; Stone, R.; Zand, B.; Kroll, M.H.; Sood, A.K.; Afshar-Kharghan, V. Platelets increase the proliferation of ovarian cancer cells. Blood 2012, 120, 4869-4872. [CrossRef] [PubMed]

48. Carr, B.I.; Cavallini, A.; D'Alessandro, R.; Refolo, M.G.; Lippolis, C.; Mazzocca, A.; Messa, C. Platelet extracts induce growth, migration and invasion in human hepatocellular carcinoma in vitro. BMC Cancer 2014, 14, 43. [CrossRef] [PubMed]

49. He, A.D.; Xie, W.; Song, W.; Ma, Y.Y.; Liu, G.; Liang, M.L.; Da, X.W.; Yao, G.Q.; Zhang, B.X.; Gao, C.J.; et al. Platelet releasates promote the proliferation of hepatocellular carcinoma cells by suppressing the expression of KLF6. Sci. Rep. 2017, 7, 3989. [CrossRef] [PubMed]

50. Narla, G.; Heath, K.E.; Reeves, H.L.; Li, D.; Giono, L.E.; Kimmelman, A.C.; Glucksman, M.J.; Narla, J.; Eng, F.J.; Chan, A.M.; et al. KLF6, a candidate tumor suppressor gene mutated in prostate cancer. Science 2001, 294, 2563-2566. [CrossRef] [PubMed]

51. Peterson, J.E.; Zurakowski, D.; Italiano, J.E., Jr.; Michel, L.V.; Connors, S.; Oenick, M.; D'Amato, R.J.; Klement, G.L.; Folkman, J. VEGF, PF4 and PDGF are elevated in platelets of colorectal cancer patients. Angiogenesis 2012, 15, 265-273. [CrossRef] [PubMed]

52. Zizzo, N.; Patruno, R.; Zito, F.A.; Di Summa, A.; Tinelli, A.; Troilo, S.; Misino, A.; Ruggieri, E.; Goffredo, V.; Gadaleta, C.D.; et al. Vascular endothelial growth factor concentrations from platelets correlate with tumor angiogenesis and grading in a spontaneous canine non-Hodgkin lymphoma model. Leuk. Lymphoma 2010, 51, 291-296. [CrossRef] [PubMed]

53. Heldin, C.H.; Lennartsson, J.; Westermark, B. Involvement of platelet-derived growth factor ligands and receptors in tumorigenesis. J. Intern. Med. 2018, 283, 16-44. [CrossRef] [PubMed] 
54. Repsold, L.; Pool, R.; Karodia, M.; Tintinger, G.; Joubert, A.M. An overview of the role of platelets in angiogenesis, apoptosis and autophagy in chronic myeloid leukaemia. Cancer Cell Int. 2017, 17, 89. [CrossRef] [PubMed]

55. Pucci, F.; Rickelt, S.; Newton, A.P.; Garris, C.; Nunes, E.; Evavold, C.; Pfirschke, C.; Engblom, C.; Mino-Kenudson, M.; Hynes, R.O.; et al. PF4 Promotes Platelet Production and Lung Cancer Growth. Cell Rep. 2016, 17, 1764-1772. [CrossRef] [PubMed]

56. Maione, T.E.; Gray, G.S.; Petro, J.; Hunt, A.J.; Donner, A.L.; Bauer, S.I.; Carson, H.F.; Sharpe, R.J. Inhibition of angiogenesis by recombinant human platelet factor-4 and related peptides. Science 1990, 247, 77-79. [CrossRef] [PubMed]

57. Yamaguchi, K.; Ogawa, K.; Katsube, T.; Shimao, K.; Konno, S.; Shimakawa, T.; Yoshimatsu, K.; Naritaka, Y.; Yagawa, H.; Hirose, K. Platelet factor 4 gene transfection into tumor cells inhibits angiogenesis, tumor growth and metastasis. Anticancer Res. 2005, 25, 847-851. [PubMed]

58. Sato, Y.; Waki, M.; Ohno, M.; Kuwano, M.; Sakata, T. Carboxyl-terminal heparin-binding fragments of platelet factor 4 retain the blocking effect on the receptor binding of basic fibroblast growth factor. Jpn. J. Cancer Res. 1993, 84, 485-488. [CrossRef] [PubMed]

59. Gengrinovitch, S.; Greenberg, S.M.; Cohen, T.; Gitay-Goren, H.; Rockwell, P.; Maione, T.E.; Levi, B.Z.; Neufeld, G. Platelet factor-4 inhibits the mitogenic activity of VEGF121 and VEGF165 using several concurrent mechanisms. J. Biol. Chem. 1995, 270, 15059-15065. [CrossRef] [PubMed]

60. Michael, J.V.; Wurtzel, J.G.T.; Mao, G.F.; Rao, A.K.; Kolpakov, M.A.; Sabri, A.; Hoffman, N.E.; Rajan, S.; Tomar, D.; Madesh, M.; et al. Platelet microparticles infiltrating solid tumors transfer miRNAs that suppress tumor growth. Blood 2017, 130, 567-580. [CrossRef] [PubMed]

61. Labelle, M.; Begum, S.; Hynes, R.O. Platelets guide the formation of early metastatic niches. Proc. Natl. Acad. Sci. USA 2014, 111, E3053-E3061. [CrossRef] [PubMed]

62. Sharma, D.; Brummel-Ziedins, K.E.; Bouchard, B.A.; Holmes, C.E. Platelets in tumor progression: A host factor that offers multiple potential targets in the treatment of cancer. J. Cell. Physiol. 2014, 229, 1005-1015. [CrossRef] [PubMed]

63. Seyfried, T.N.; Huysentruyt, L.C. On the origin of cancer metastasis. Crit. Rev. Oncog. 2013, 18, 43-73. [CrossRef] [PubMed]

64. Gasic, G.J.; Gasic, T.B.; Stewart, C.C. Antimetastatic effects associated with platelet reduction. Proc. Natl. Acad. Sci. USA 1968, 61, 46-52. [CrossRef] [PubMed]

65. Gasic, G.J.; Gasic, T.B.; Galanti, N.; Johnson, T.; Murphy, S. Platelet-tumor-cell interactions in mice. The role of platelets in the spread of malignant disease. Int. J. Cancer 1973, 11, 704-718. [CrossRef] [PubMed]

66. Mitchell, M.J.; King, M.R. Fluid Shear Stress Sensitizes Cancer Cells to Receptor-Mediated Apoptosis via Trimeric Death Receptors. New J. Phys. 2013, 15. [CrossRef] [PubMed]

67. Egan, K.; Cooke, N.; Kenny, D. Living in shear: Platelets protect cancer cells from shear induced damage. Clin. Exp. Metast. 2014, 31, 697-704. [CrossRef] [PubMed]

68. Thiery, J.P.; Acloque, H.; Huang, R.Y.; Nieto, M.A. Epithelial-mesenchymal transitions in development and disease. Cell 2009, 139, 871-890. [CrossRef] [PubMed]

69. Yeung, K.T.; Yang, J. Epithelial-mesenchymal transition in tumor metastasis. Mol. Oncol. 2017, 11, $28-39$. [CrossRef] [PubMed]

70. Takemoto, A.; Okitaka, M.; Takagi, S.; Takami, M.; Sato, S.; Nishio, M.; Okumura, S.; Fujita, N. A critical role of platelet TGF-beta release in podoplanin-mediated tumour invasion and metastasis. Sci. Rep. 2017, 7, 42186. [CrossRef] [PubMed]

71. Labelle, M.; Begum, S.; Hynes, R.O. Direct signaling between platelets and cancer cells induces an epithelialmesenchymal-like transition and promotes metastasis. Cancer Cell 2011, 20, 576-590. [CrossRef] [PubMed]

72. Tang, M.; Jiang, L.; Lin, Y.; Wu, X.; Wang, K.; He, Q.; Wang, X.; Li, W. Platelet microparticle-mediated transfer of miR-939 to epithelial ovarian cancer cells promotes epithelial to mesenchymal transition. Oncotarget 2017, 8, 97464-97475. [CrossRef] [PubMed]

73. Fujita, N.; Takagi, S. The impact of Aggrus/podoplanin on platelet aggregation and tumour metastasis. J. Biochem. 2012, 152, 407-413. [CrossRef] [PubMed]

74. Ruf, W. Tissue factor and cancer. Thromb. Res. 2012, 130 (Suppl. 1), S84-S87. [CrossRef] [PubMed] 
75. Orellana, R.; Kato, S.; Erices, R.; Bravo, M.L.; Gonzalez, P.; Oliva, B.; Cubillos, S.; Valdivia, A.; Ibanez, C.; Branes, J.; et al. Platelets enhance tissue factor protein and metastasis initiating cell markers, and act as chemoattractants increasing the migration of ovarian cancer cells. BMC Cancer 2015, 15, 290. [CrossRef] [PubMed]

76. Dovizio, M.; Maier, T.J.; Alberti, S.; Di Francesco, L.; Marcantoni, E.; Munch, G.; John, C.M.; Suess, B.; Sgambato, A.; Steinhilber, D.; et al. Pharmacological inhibition of platelet-tumor cell cross-talk prevents platelet-induced overexpression of cyclooxygenase-2 in HT29 human colon carcinoma cells. Mol. Pharmacol. 2013, 84, 25-40. [CrossRef] [PubMed]

77. Xu, X.R.; Carrim, N.; Neves, M.A.; McKeown, T.; Stratton, T.W.; Coelho, R.M.; Lei, X.; Chen, P.; Xu, J.; Dai, X.; et al. Platelets and platelet adhesion molecules: Novel mechanisms of thrombosis and anti-thrombotic therapies. Thromb. J. 2016, 14 (Suppl. 1), 29. [CrossRef] [PubMed]

78. Lavergne, M.; Janus-Bell, E.; Schaff, M.; Gachet, C.; Mangin, P.H. Platelet Integrins in Tumor Metastasis: Do They Represent a Therapeutic Target? Cancers 2017, 9, 133. [CrossRef] [PubMed]

79. Mammadova-Bach, E.; Zigrino, P.; Brucker, C.; Bourdon, C.; Freund, M.; De Arcangelis, A.; Abrams, S.I.; Orend, G.; Gachet, C.; Mangin, P.H. Platelet integrin alpha6beta1 controls lung metastasis through direct binding to cancer cell-derived ADAM9. JCI Insight 2016, 1, e88245. [CrossRef] [PubMed]

80. Bakewell, S.J.; Nestor, P.; Prasad, S.; Tomasson, M.H.; Dowland, N.; Mehrotra, M.; Scarborough, R.; Kanter, J.; Abe, K.; Phillips, D.; et al. Platelet and osteoclast beta3 integrins are critical for bone metastasis. Proc. Natl. Acad. Sci. USA 2003, 100, 14205-14210. [CrossRef] [PubMed]

81. Boucharaba, A.; Serre, C.M.; Gres, S.; Saulnier-Blache, J.S.; Bordet, J.C.; Guglielmi, J.; Clezardin, P.; Peyruchaud, O. Platelet-derived lysophosphatidic acid supports the progression of osteolytic bone metastases in breast cancer. J. Clin. Investig. 2004, 114, 1714-1725. [CrossRef] [PubMed]

82. Chopra, H.; Hatfield, J.S.; Chang, Y.S.; Grossi, I.M.; Fitzgerald, L.A.; O'Gara, C.Y.; Marnett, L.J.; Diglio, C.A.; Taylor, J.D.; Honn, K.V. Role of tumor cytoskeleton and membrane glycoprotein IRGpIIb/IIIa in platelet adhesion to tumor cell membrane and tumor cell-induced platelet aggregation. Cancer Res. 1988, 48, 3787-3800. [PubMed]

83. Frisch, S.M.; Screaton, R.A. Anoikis mechanisms. Curr. Opin. Cell Biol. 2001, 13, 555-562. [CrossRef]

84. Buchheit, C.L.; Weigel, K.J.; Schafer, Z.T. Cancer cell survival during detachment from the ECM: Multiple barriers to tumour progression. Nat. Rev. Cancer 2014, 14, 632-641. [CrossRef] [PubMed]

85. Haemmerle, M.; Taylor, M.L.; Gutschner, T.; Pradeep, S.; Cho, M.S.; Sheng, J.; Lyons, Y.M.; Nagaraja, A.S.; Dood, R.L.; Wen, Y.; et al. Platelets reduce anoikis and promote metastasis by activating YAP1 signaling. Nat. Commun. 2017, 8, 310. [CrossRef] [PubMed]

86. Ichijo, H.; Nishida, E.; Irie, K.; ten Dijke, P.; Saitoh, M.; Moriguchi, T.; Takagi, M.; Matsumoto, K.; Miyazono, K.; Gotoh, Y. Induction of apoptosis by ASK1, a mammalian MAPKKK that activates SAPK/JNK and p38 signaling pathways. Science 1997, 275, 90-94. [CrossRef] [PubMed]

87. Kamiyama, M.; Shirai, T.; Tamura, S.; Suzuki-Inoue, K.; Ehata, S.; Takahashi, K.; Miyazono, K.; Hayakawa, Y.; Sato, T.; Takeda, K.; et al. ASK1 facilitates tumor metastasis through phosphorylation of an ADP receptor P2Y12 in platelets. Cell Death Differ. 2017, 24, 2066-2076. [CrossRef] [PubMed]

88. Carpinteiro, A.; Becker, K.A.; Japtok, L.; Hessler, G.; Keitsch, S.; Pozgajova, M.; Schmid, K.W.; Adams, C.; Muller, S.; Kleuser, B.; et al. Regulation of hematogenous tumor metastasis by acid sphingomyelinase. EMBO Mol. Med. 2015, 7, 714-734. [CrossRef] [PubMed]

89. Carpinteiro, A.; Beckmann, N.; Seitz, A.; Hessler, G.; Wilker, B.; Soddemann, M.; Helfrich, I.; Edelmann, B.; Gulbins, E.; Becker, K.A. Role of Acid Sphingomyelinase-Induced Signaling in Melanoma Cells for Hematogenous Tumor Metastasis. Cell. Physiol. Biochem. 2016, 38, 1-14. [CrossRef] [PubMed]

90. Wargo, J.A.; Schumacher, L.Y.; Comin-Anduix, B.; Dissette, V.B.; Glaspy, J.A.; McBride, W.H.; Butterfield, L.H.; Economou, J.S.; Ribas, A. Natural killer cells play a critical role in the immune response following immunization with melanoma-antigen-engineered dendritic cells. Cancer Gene Ther. 2005, 12, $516-527$. [CrossRef] [PubMed]

91. Shimaoka, H.; Takeno, S.; Maki, K.; Sasaki, T.; Hasegawa, S.; Yamashita, Y. A cytokine signal inhibitor for rheumatoid arthritis enhances cancer metastasis via depletion of NK cells in an experimental lung metastasis mouse model of colon cancer. Oncol. Lett. 2017, 14, 3019-3027. [CrossRef] [PubMed]

92. Nieswandt, B.; Hafner, M.; Echtenacher, B.; Mannel, D.N. Lysis of tumor cells by natural killer cells in mice is impeded by platelets. Cancer Res. 1999, 59, 1295-1300. [PubMed] 
93. Zitvogel, L.; Tesniere, A.; Kroemer, G. Cancer despite immunosurveillance: Immunoselection and immunosubversion. Nat. Rev. Immunol. 2006, 6, 715-727. [CrossRef] [PubMed]

94. Placke, T.; Orgel, M.; Schaller, M.; Jung, G.; Rammensee, H.G.; Kopp, H.G.; Salih, H.R. Platelet-derived MHC class I confers a pseudonormal phenotype to cancer cells that subverts the antitumor reactivity of natural killer immune cells. Cancer Res. 2012, 72, 440-448. [CrossRef] [PubMed]

95. Kopp, H.G.; Placke, T.; Salih, H.R. Platelet-derived transforming growth factor-beta down-regulates NKG2D thereby inhibiting natural killer cell antitumor reactivity. Cancer Res. 2009, 69, 7775-7783. [CrossRef] [PubMed]

96. Fadok, V.A.; Bratton, D.L.; Konowal, A.; Freed, P.W.; Westcott, J.Y.; Henson, P.M. Macrophages that have ingested apoptotic cells in vitro inhibit proinflammatory cytokine production through autocrine/paracrine mechanisms involving TGF-beta, PGE2, and PAF. J. Clin. Investig. 1998, 101, 890-898. [CrossRef] [PubMed]

97. Haribhai, D.; Luo, X.; Chen, J.; Jia, S.; Shi, L.; Schroeder, J.A.; Weiler, H.; Aster, R.H.; Hessner, M.J.; Hu, J.; et al. TGF-beta1 along with other platelet contents augments Treg cells to suppress anti-FVIII immune responses in hemophilia A mice. Blood Adv. 2016, 1, 139-151. [CrossRef] [PubMed]

98. Grossman, W.J.; Verbsky, J.W.; Barchet, W.; Colonna, M.; Atkinson, J.P.; Ley, T.J. Human T regulatory cells can use the perforin pathway to cause autologous target cell death. Immunity 2004, 21, 589-601. [CrossRef] [PubMed]

99. Gondek, D.C.; Lu, L.F.; Quezada, S.A.; Sakaguchi, S.; Noelle, R.J. Cutting edge: Contact-mediated suppression by CD4+CD25+ regulatory cells involves a granzyme B-dependent, perforin-independent mechanism. J. Immunol. 2005, 174, 1783-1786. [CrossRef] [PubMed]

100. Tran, D.Q.; Andersson, J.; Wang, R.; Ramsey, H.; Unutmaz, D.; Shevach, E.M. GARP (LRRC32) is essential for the surface expression of latent TGF-beta on platelets and activated FOXP3+ regulatory T cells. Proc. Natl. Acad. Sci. USA 2009, 106, 13445-13450. [CrossRef] [PubMed]

101. Rachidi, S.; Metelli, A.; Riesenberg, B.; Wu, B.X.; Nelson, M.H.; Wallace, C.; Paulos, C.M.; Rubinstein, M.P.; Garrett-Mayer, E.; Hennig, M.; et al. Platelets subvert T cell immunity against cancer via GARP-TGFbeta axis. Sci. Immunol. 2017, 2, 11. [CrossRef] [PubMed]

102. Silverstein, M.D.; Heit, J.A.; Mohr, D.N.; Petterson, T.M.; O'Fallon, W.M.; Melton, L.J. Trends in the incidence of deep vein thrombosis and pulmonary embolism: A 25-year population-based study. Arch. Intern. Med. 1998, 158, 585-593. [CrossRef] [PubMed]

103. Gomes, F.G.; Sandim, V.; Almeida, V.H.; Rondon, A.M.R.; Succar, B.B.; Hottz, E.D.; Leal, A.C.; Vercoza, B.R.F.; Rodrigues, J.C.F.; Bozza, P.T.; et al. Breast-cancer extracellular vesicles induce platelet activation and aggregation by tissue factor-independent and -dependent mechanisms. Thromb. Res. 2017, 159, $24-32$. [CrossRef] [PubMed]

104. Ferroni, P.; Santilli, F.; Cavaliere, F.; Simeone, P.; Costarelli, L.; Liani, R.; Tripaldi, R.; Riondino, S.; Roselli, M.; Davi, G.; et al. Oxidant stress as a major determinant of platelet activation in invasive breast cancer. Int. J. Cancer 2017, 140, 696-704. [CrossRef] [PubMed]

105. Lindeman, J.H.; Hanemaaijer, R.; Mulder, A.; Dijkstra, P.D.; Szuhai, K.; Bromme, D.; Verheijen, J.H.; Hogendoorn, P.C. Cathepsin K is the principal protease in giant cell tumor of bone. Am. J. Pathol. 2004, 165, 593-600. [CrossRef]

106. Chen, B.; Platt, M.O. Multiplex zymography captures stage-specific activity profiles of cathepsins K, L, and S in human breast, lung, and cervical cancer. J. Transl. Med. 2011, 9, 109. [CrossRef] [PubMed]

107. Andrade, S.S.; Gouvea, I.E.; Silva, M.C.; Castro, E.D.; de Paula, C.A.; Okamoto, D.; Oliveira, L.; Peres, G.B.; Ottaiano, T.; Facina, G.; et al. Cathepsin K induces platelet dysfunction and affects cell signaling in breast cancer -molecularly distinct behavior of cathepsin $\mathrm{K}$ in breast cancer. BMC Cancer 2016, 16, 173. [CrossRef] [PubMed]

108. Hu, Q.; Wang, M.; Cho, M.S.; Wang, C.; Nick, A.M.; Thiagarajan, P.; Aung, F.M.; Han, X.; Sood, A.K.; Afshar-Kharghan, V. Lipid profile of platelets and platelet-derived microparticles in ovarian cancer. BBA Clin. 2016, 6, 76-81. [CrossRef] [PubMed]

109. Feng, S.; Kroll, M.H.; Nick, A.M.; Sood, A.K.; Afshar-Kharghan, V. Platelets are not hyperreactive in patients with ovarian cancer. Platelets 2016, 27, 716-718. [CrossRef] [PubMed]

110. Cuzick, J.; Thorat, M.A.; Bosetti, C.; Brown, P.H.; Burn, J.; Cook, N.R.; Ford, L.G.; Jacobs, E.J.; Jankowski, J.A.; La Vecchia, C.; et al. Estimates of benefits and harms of prophylactic use of aspirin in the general population. Ann. Oncol. 2015, 26, 47-57. [CrossRef] [PubMed]

111. Vane, J. Towards a better aspirin. Nature 1994, 367, 215-216. [CrossRef] [PubMed] 
112. Guillem-Llobat, P.; Dovizio, M.; Bruno, A.; Ricciotti, E.; Cufino, V.; Sacco, A.; Grande, R.; Alberti, S.; Arena, V.; Cirillo, M.; et al. Aspirin prevents colorectal cancer metastasis in mice by splitting the crosstalk between platelets and tumor cells. Oncotarget 2016, 7, 32462-32477. [CrossRef] [PubMed]

113. Lichtenberger, L.M.; Fang, D.; Bick, R.J.; Poindexter, B.J.; Phan, T.; Bergeron, A.L.; Pradhan, S.; Dial, E.J.; Vijayan, K.V. Unlocking Aspirin's Chemopreventive Activity: Role of Irreversibly Inhibiting Platelet Cyclooxygenase-1. Cancer Prev. Res. 2017, 10, 142-152. [CrossRef] [PubMed]

114. Sandler, R.S.; Halabi, S.; Baron, J.A.; Budinger, S.; Paskett, E.; Keresztes, R.; Petrelli, N.; Pipas, J.M.; Karp, D.D.; Loprinzi, C.L.; et al. A randomized trial of aspirin to prevent colorectal adenomas in patients with previous colorectal cancer. N. Engl. J. Med. 2003, 348, 883-890. [CrossRef] [PubMed]

115. Fisher, B.; Costantino, J.P.; Wickerham, D.L.; Cecchini, R.S.; Cronin, W.M.; Robidoux, A.; Bevers, T.B.; Kavanah, M.T.; Atkins, J.N.; Margolese, R.G.; et al. Tamoxifen for the prevention of breast cancer: Current status of the National Surgical Adjuvant Breast and Bowel Project P-1 study. J. Natl. Cancer Inst. 2005, 97, 1652-1662. [CrossRef] [PubMed]

116. Johnson, K.E.; Forward, J.A.; Tippy, M.D.; Ceglowski, J.R.; El-Husayni, S.; Kulenthirarajan, R.; Machlus, K.R.; Mayer, E.L.; Italiano, J.E., Jr.; Battinelli, E.M. Tamoxifen Directly Inhibits Platelet Angiogenic Potential and Platelet-Mediated Metastasis. Arterioscler. Thromb. Vasc. Biol. 2017, 37, 664-674. [CrossRef] [PubMed]

117. Zhang, Y.; Wei, J.; Liu, S.; Wang, J.; Han, X.; Qin, H.; Lang, J.; Cheng, K.; Li, Y.; Qi, Y.; et al. Inhibition of platelet function using liposomal nanoparticles blocks tumor metastasis. Theranostics 2017, 7, 1062-1071. [CrossRef] [PubMed]

118. Chang, Y.W.; Hsieh, P.W.; Chang, Y.T.; Lu, M.H.; Huang, T.F.; Chong, K.Y.; Liao, H.R.; Cheng, J.C.; Tseng, C.P. Identification of a novel platelet antagonist that binds to CLEC-2 and suppresses podoplanin-induced platelet aggregation and cancer metastasis. Oncotarget 2015, 6, 42733-42738. [CrossRef] [PubMed]

119. Gresele, P.; Momi, S.; Falcinelli, E. Anti-platelet therapy: Phosphodiesterase inhibitors. Br. J. Clin. Pharmacol. 2011, 72, 634-646. [CrossRef] [PubMed]

120. Rondina, M.T.; Weyrich, A.S. Targeting phosphodiesterases in anti-platelet therapy. Handb. Exp. Pharmacol. 2012, 210, 225-238.

121. Uzawa, K.; Kasamatsu, A.; Baba, T.; Usukura, K.; Saito, Y.; Sakuma, K.; Iyoda, M.; Sakamoto, Y.; Ogawara, K.; Shiiba, M.; et al. Targeting phosphodiesterase 3B enhances cisplatin sensitivity in human cancer cells. Cancer Med. 2013, 2, 40-49. [CrossRef] [PubMed]

122. Tzanakakis, G.N.; Agarwal, K.C.; Vezeridis, M.P. Prevention of human pancreatic cancer cell-induced hepatic metastasis in nude mice by dipyridamole and its analog RA-233. Cancer 1993, 71, 2466-24671. [CrossRef]

123. Desai, P.B.; Duan, J.; Sridhar, R.; Damle, B.D. Reversal of doxorubicin resistance in multidrug resistant melanoma cells in vitro and in vivo by dipyridamole. Methods Find. Exp. Clin. Pharmacol. 1997, 19, 231-239. [PubMed]

124. Amirkhosravi, A.; Mousa, S.A.; Amaya, M.; Blaydes, S.; Desai, H.; Meyer, T.; Francis, J.L. Inhibition of tumor cell-induced platelet aggregation and lung metastasis by the oral GpIIb/IIIa antagonist XV454. Thromb. Haemost. 2003, 90, 549-554. [CrossRef] [PubMed]

125. Ishikawa, S.; Miyashita, T.; Inokuchi, M.; Hayashi, H.; Oyama, K.; Tajima, H.; Takamura, H.; Ninomiya, I.; Ahmed, A.K.; Harman, J.W.; et al. Platelets surrounding primary tumor cells are related to chemoresistance. Oncol. Rep. 2016, 36, 787-794. [CrossRef] [PubMed]

126. Haslehurst, A.M.; Koti, M.; Dharsee, M.; Nuin, P.; Evans, K.; Geraci, J.; Childs, T.; Chen, J.; Li, J.; Weberpals, J.; et al. EMT transcription factors snail and slug directly contribute to cisplatin resistance in ovarian cancer. BMC Cancer 2012, 12, 91. [CrossRef] [PubMed]

127. Tsukasa, K.; Ding, Q.; Yoshimitsu, M.; Miyazaki, Y.; Matsubara, S.; Takao, S. Slug contributes to gemcitabine resistance through epithelial-mesenchymal transition in CD133(+) pancreatic cancer cells. Hum. Cell 2015, 28, 167-174. [CrossRef] [PubMed]

128. Sarkar, S.; Alam, M.A.; Shaw, J.; Dasgupta, A.K. Drug delivery using platelet cancer cell interaction. Pharm. Res. 2013, 30, 2785-2794. [CrossRef] [PubMed]

129. Xu, P.; Zuo, H.; Zhou, R.; Wang, F.; Liu, X.; Ouyang, J.; Chen, B. Doxorubicin-loaded platelets conjugated with anti-CD22 mAbs: A novel targeted delivery system for lymphoma treatment with cardiopulmonary avoidance. Oncotarget 2017, 8, 58322-58337. [CrossRef] [PubMed] 
130. Xu, P.; Zuo, H.; Chen, B.; Wang, R.; Ahmed, A.; Hu, Y.; Ouyang, J. Doxorubicin-loaded platelets as a smart drug delivery system: An improved therapy for lymphoma. Sci. Rep. 2017, 7, 42632. [CrossRef] [PubMed]

131. Li, J.; Ai, Y.; Wang, L.; Bu, P.; Sharkey, C.C.; Wu, Q.; Wun, B.; Roy, S.; Shen, X.; King, M.R. Targeted drug delivery to circulating tumor cells via platelet membrane-functionalized particles. Biomaterials 2016, 76, 52-65. [CrossRef] [PubMed] 